\title{
Perception of risk sources by chilean blueberry producers
}

\begin{abstract}
Germán Lobos ${ }^{1}$, Berta Schnettler ${ }^{2}$, Carlos Mena ${ }^{3}$, Yony Ormazábal ${ }^{4}$, Juan Carlos Cantillana ${ }^{5}$, Jorge Borrar Retamales ${ }^{6}$

Abstract - The biological and environmental nature of the agricultural production implies that growers operate in an environment of greater risk as compared to other economic activities. This has implications on the manner in which the growers can manage the risks inherent to their activity, which depends on how they perceive the risks and on the degree of aversion to risk. The main objective of this study was to learn about the perception of the main sources of risk that blueberry growers face in the Maule Region, Chile. This Region has about $25 \%$ of the planted area of this species in Chile. We used information from questionnaires implemented in 124 fields which considered two independent groups of growers: 48 owners and 76 managers. A scale of Importance of the Sources of Risk (ISR) was used. It included 13 items that the interviewed had to rank according to their importance through a Likert-type scale of four levels. The exploratory analysis allowed to infer that the ISR scale had adequate levels of internal consistency (Cronbach's alpha $=0.83$ ). The results showed that the climatic events are perceived by the growers as the main source of risk for blueberry production in Chile. The analysis also showed that the price of the product and the currency exchange rate are the next risks in importance for the field owners. On the other hand, the risks for the managers were, in decreasing order of importance: yield, product price, variability in sales, and volumes for sale. The knowledge of the perception of risk by the growers is a fundamental input for designing instruments of agricultural policies, risk management and support programs for the growers.
\end{abstract}

Index Terms: Risk and uncertainty; climatic events; risk management.

\section{Percepção das fontes de risco pelos produtores chilenos de mirtilo}

\section{Corresponding author:} globos@utalca.cl

Received: September 22, 2017. Accepted : March 07, 2018.

Copyright: All the contents of this journal, except where otherwise noted, is licensed under a Creative Commons Attribution License.

Resumo - A natureza biológica e climática da produção agrícola implica que os produtores operem em um ambiente de maior risco, comparado às outras atividades econômicas. Isto tem implicações na forma com que os produtores podem gerir os riscos inerentes à sua atividade, que depende de como eles percebem os riscos e o grau de aversão ao risco. O principal objetivo desta pesquisa foi investigar a percepção das principais fontes de risco enfrentadas pelos produtores de mirtilo na região de Maule, Chile, que atinge cerca de $25 \%$ da área cultivada da espécie. Informação de questionários realizados em 124 pomares foi utilizada, considerando dois grupos independentes de produtores: 48 proprietários e 76 administradores. A escala de importância das fontes de risco (ISR) foi utilizada. Ela incluiu 13 itens a que os entrevistados deveriam responder de acordo com sua importância, em uma escala tipo Likert, de quatro níveis. A análise exploratória possibilitou inferir que a escala ISR apresentou níveis adequados de consistência interna (alfa de Cronbach $=0,83$ ). Os resultados mostraram que os eventos climáticos são percebidos pelos agricultores como a principal fonte de risco na produção de mirtilo no Chile. A análise também mostrou que o preço do produto e da taxa de câmbio se encontram próximos em importância para os proprietários, enquanto para os gestores foram, em ordem decrescente, a performance, o preço do produto e a variabilidade de vendas. $\mathrm{O}$ conhecimento da percepção dos agricultores sobre o risco é um fator da produção essencial para a elaboração de instrumentos de política agrícola, gestão de riscos e programas de apoio aos produtores. Termos de indexação: Risco e incerteza; eventos climáticos; gestão de riscos.

\footnotetext{
${ }^{1}$ Dr., Facultad de Economía y Negocios, Universidad de Talca.Talca, Chile. E-mail: globos@utalca.cl

${ }^{2}$ Dra., Facultad de Ciencias Agropecuarias y Forestales. Universidad de La Fronteira. Temuco, Chile. E-mail: berta.schnettler@ufrontera.cl

${ }^{3}$ Dr., Facultad de Ciencias Forestales, Universidad de Talca, Chile. E-mail: cmena@utalca.cl

${ }^{4}$ M.Sc., Facultad de Ciencias Forestales, Universidad de Talca, Chile. E-mail: yormazabal@utalca.cl

${ }^{5} \mathrm{Mg}$., Facultad de Administración y Economía, Universidad Tecnológica Metropolitana. Colchagua, O’Higgins .Chile. E-mail: juan.cantillana@utem.cl

${ }^{6}$ Ph.D., Facultad de Ciencias Agrarias, Universidad de Talca. Talca, Chile. E-mail: jretamal@utalca.cl
} 


\section{Introduction}

In the last years blueberries (Vaccinium sp.) have increased they area planted worldwide as a consequence of the expansion in consumption due to the benefits for human health (RETAMALES; HANCOCK, 2012). Currently the area planted with blueberries in Chile reaches 15,998 ha (ODEPA-CIREN, 2016), which represents nearly $20 \%$ of the area planted in the world. Thus, Chile ranks second behind USA on a worldwide basis as blueberry producing country. Although the main objective of the Chilean blueberry industry is to reach the markets with high quality fresh fruit, it is expected to continue the expansion of frozen blueberries to markets such as USA, South Korea, Australia and Canada. In the 2016-2017 season, the volume exported as fresh fruit was 110.826 tons, which was shipped mainly to USA followed by Europe (ODEPA, 2017).

The Maule (Lat. $34^{\circ} 31^{\prime}$ to $36^{\circ} 33^{\prime} \mathrm{S}$ ) and BioBio $\left(36^{\circ} 33^{\prime}\right.$ to $\left.38^{\circ} 30^{\prime} \mathrm{S}\right)$ regions are the main blueberry producing ones in the country. The area planted with blueberries in both regions increased 2.4 fold between 2007 and 2012 (CIREN, 2014). Soil characteristics (texture, $\mathrm{pH}$, depth, acidity) as well as the Mediterranean and subtropical climates in these regions allow adequate development of blueberries (CAZANGA; LEIVA, 2013). According to MENA (2013), in the Maule Region there are 185 blueberry growers that own 216 commercial fields, with a total planted area of 2,865 ha which represents nearly $25 \%$ of the national total for this crop (Figure 1 ).

The biological and climatic nature of the agricultural production implies that the growers operate in an environment of greater risk and uncertainty than other economic activities (AĞIR et al., 2015; ULLAH et al., 2015a). This could compromise economic viability of the crops (SIMÕES et al., 2015). In fact, according to ULLAH et al. (2015b), weather is an important production factor in agriculture and this production factor can hardly be controlled. This has a major impinging on the main decision making, such as investment, production, marketing and finances. According to SULEWSKI; KŁOCZKO-GAJEWSKA (2014), the application of an adequate strategy for risk management is related to the perception and aversion to risk by the growers. This explains the growing interest by agricultural growers in the area of risk management. CAO et al. (2011) noted that the study of the attitude towards risk is more recent that the research on risk perception. However, adequate measurements of risk perception and risk aversion are crucial to understand the economical behavior of the growers and how they manage risks.

Traditionally the main sources of risk in agriculture have been associated with variability in yields and prices, as well as technological advances and agricultural policies (DILLON, 1971; ANDERSON et al., 1977; NEWBERY;
STIGLITZ, 1981). In the last years the literature recognizes the following risks as most relevant: yield and prices, loss of assets, institutional, legal and environmental, personnel, and financial (BAQUET et al., 1997; JUST; POPE, 2002; HARDAKER et al., 2004). More recently, some authors have mentioned the increasing risk associated with climate change (KUNDZEWICZ; KOZYRA, 2011; OLESEN et al., 2011; SULEWSKI; KŁOCZKO-GAJEWSKA, 2014).

The literature reports on various strategies and tools for adequate decision making in agriculture (MOSCHINI ; HENNESSY, 2001; HARDAKER et al., 2004). Although most studies have concentrated in identifying the sources of risk that are perceived as the most important by the growers, the way in which the growers assess and manage risk in real life are fundamental aspects (FLATEN et al., 2004; ULLAH et al., 2015b). For example, North American farmers perceive as most relevant the risk of the prices in the commodities, yield, legal and regulatory changes (HARWOOD et al., 1999); cost of inputs (WILSON et al., 1993); severe droughts (GREINER et al., 2008) and prices of animals (HALL et al., 2003). The price of milk and the variability in rainfall are the most relevant risks for New Zealand milk farmers (MARTIN, 1996); volatility in prices and yields are the most important risks for Dutch ranchers (MEUWISSEN et al., 2001); variability in agricultural policies are the main risks for Finish farmers (SONKKILA, 2002); while institutional risks are the main ones for organic and conventional Norwegian milk producers (FLATEN et al., 2004). GEBREEGZIABHER and TADESSE (2014) focused on farmers' risk perception and management strategies of smallholder dairy farms in urban and peri-urban areas of Tigray in northern Ethiopia. Based on data collected from a sample of 304 dairy farm smallholders, factor analysis identified technological, price/market, production, financial, human, and institutional factors as major sources of risks. ULLAH et al. (2016) distinguished two major types of risk in agriculture; first, business risk which include production, market, institutional and personal risks; second, financial risks resulting from different methods of financing the farm business. AĞIR et al. (2015) determined farmers' risk perceptions, risk management strategies in strawberry production under open field in Menemen-Emiralem district of Izmir province in Turkey. The results of this study showed that the most important risk resource that the strawberry farmers' perceive arise from the lack of production capacity. ULLAH et al. (2015b and 2016) analyzed factors affecting farmers' decisions of adopting diversification, precautionary savings and agricultural credit as risk management. According to these studies the decisions about the adoption of risk management tools are influenced by variety of factors including farm and farm household characteristics, farmers' perceptions of production risk sources, their attitude towards risk and their access to information and credit sources. BAGHERI; 
FAMI (2016) examined potato growers' perceptions of risk sources and risk management strategies and their risk management behavior. These authors concluded that potato price, marketing and yield were important sources of risk. In a sample of 38 randomly-selected winegrowers in the Croatian northwestern sub region of Zagorje Međimurje, SMRKULJ;NJAVRO (2016) found that highly important risk sources were health issues (human risks) and production risks (weather factors, as well as diseases and pests). Finally, SAINT-GEOURS et al. (2015) concluded that the ranking of uncertainty sources depends not only on the economic sector considered (private housing, agricultural land, other economic activities), but also on a number of averaging-out effects controlled by the number and surface area of the assets considered, the number of land use types or the number of damage functions.

The explosive growth in the area planted with blueberries in Chile, along with the volumes produced and the sales have brought greater exposure to risks for this activity. Besides it is relevant to consider that during the 2016/17 season blueberries ranked sixth among the exported fruit from Chile and placed this country as the main fresh blueberry exporter in the world. In this context as sources of risk not only is important the volatility in international agricultural commodities (BUGUK et al., 2003), but in the case of Chile should be kept in mind that the exporting companies pass on to the fruit growers a greater proportion of the volatility in prices than the one they are facing in the international markets (LOBOS; PETRI, 2008). Considering these two conditionings, the justification of this study derives from the interest in knowing how the Chilean blueberry producers perceive the risks they face. The first conditioning is that in developing countries such as Chile studies on the perceptions of risk have received little attention in agricultural research (GEBREEGZIABHER; TADESSE, 2014); the second is that in general in the developing countries have available relatively few instruments for agricultural risk management. As KHAN et al. (2017) suggest this could help governments in developing countries to define agricultural risk management strategies that can be used as powerful tools for economic development of agriculture.

However, the differences in risk perception for farms of similar size should reflect differences in the level of exposure to risk (SULEWSKI; KŁOCZKOGAJEWSKA, 2014). For example, the perception of risk can be different in blueberry fields of different size, which can be defined according to some criterion of the scale of production, such as amount of investment, planted area or number of permanent workers employed. In this context, this research aims to contribute to the understanding of how blueberry growers perceive the main sources of risk that they face. According to LOBOS; VIVIANI (2010), this implies identifying which are the subjacent attitudes, which includes the degree of aversion to risk by the growers. This also means that an appropriate perception of risk can be seen as a necessary condition to adopt an effective strategy to manage risk (MEUWISSEN et al., 2001; NGUYEN et al., 2007; SULEWSKI; KŁOCZKO-GAJEWSKA, 2014). On the other hand, the cultivation of blueberry fields in Chile is done by two types of growers: owners and managers. Both groups have different motivations; they operate in conditions of imperfect information, and are willing to assume different levels of risk (SAN MARTÍN, 2012). In this situation, an agency problem could evolve which implies different perceptions of the sources of risk. In this case the owners fulfill the role of principal and the managers the role of agent. Following the theory of agency by JENSEN and MECKLING (1976), the conflict of interests between the principal and the agent translates into a problem of the agency. The findings from this study can help governmental agencies, extensionists and researchers in two manners. First, those responsible of the agricultural policies can identify the sources of risks perceived as the most important by the growers and then design instruments which are adequate for managing agricultural, either by financial coverage or public instruments. Second, it can help growers to understand how they perceive risks and take better decisions managing risks.

Based on the above information, the main objective of this research was to learn about the perception of the main sources of risks that are facing the blueberry growers in the Maule Region, Chile. It was also established two specific objectives, considering three field sizes based on the number of permanent workers: 1) Rank the sources of risk according to the importance assigned by the growers, and 2) compare the perception of the sources of risk among the field owners and the field managers.

\section{Materials and Methods}

\section{The sample}

In the Maule Region in 2013 there were 185 blueberry growers which own a total of 216 commercial fields (MENA, 2013). There is a marked spatial distribution pattern of these growers which increase in their concentration in the north-south axis (Figure 1). As a criterion of inclusion of the total number of growers, we selected those that produce one of the four cultivars with largest fruit volumes in the Maule Region: Brigitta, Duke, Legacy and O'Neal (MENA, 2013). This allowed us to reduce the universe to 156 growers. The data were collected by means of face-to-face interviews with growers. The grower was then informed of the objectives and participated voluntarily, having the opportunity to read the content of the instrument and respond freely to the questionnaire. A convenience sample was applied to two independent groups of growers $\left(n_{l}=\right.$ owners and 
$n_{2}=$ managers ). To determine the size of the sample for each group, an analysis of power was carried out using the software G*power 3.1 (FAUL et al., 2009). The a priori analysis established a minimum sample size of $n_{1}=n_{2}=35$ (size of the effect: $\mathrm{d}=0.8$; Cronbach's alpha $=0.05$; power $(1-\beta)=0.95$; allocation ratio $\left.n_{2} / n_{1}=1.00\right)$. The post hoc analysis, considering the expectation of lost data and/or error in the responses $n_{1}=48$ and $n_{2}=76$, showed that the power was $(1-\beta)=0.99$ (size of the effect: $d=0.8$; Cronbach's alpha $=0.05$; allocation ratio $n_{1} / n_{2}=0.63$ ).

\section{Instrument}

In this study we used the scale of sources of risk reported by LOBOS and VIVIANI (2010), which was used to study the perceptions of sources of risks of Chilean wine grape growers. That scale was adapted from the instrument applied by GARCÍA (2006) in a sample of wine grape growers of all French wine regions. To gather the information a questionnaire was applied which allowed knowing about the importance assigned by the growers to 13 sources of risk regarding their blueberry business. We also learned about the size of their operations in terms of the number of permanent workers, the range of ages among the owners, the participation in the capital of the company, and the individual perceptions regarding various alternatives of investment. Thus, the scale of Importance of Sources of Risk (ISR) included 13 items which the interviewed had to rank according to their importance through a Likert scale of four levels $(1=$ irrelevant to $4=$ very relevant). The implicit intention is that the perception of the growers would reflect the potential impact of each source of risk on the objectives of the enterprise. The exploratory analysis allowed us to infer that the ISR scale had an adequate level of internal consistency (Cronbach's alpha $=0.83$ ), as well as the existence of a single factor for all the items $(\mathrm{KMO}=0.75 ; p<0.01)$. The importance of each source of risk was obtained from the scores of the items in the scale (range: 1-4). The importance of the set of risk sources was obtained from the addition of the scores in the items of the scale (range: 27-52). A higher score in the scale reflects a greater importance assigned to a given source of risk. Thus, the ISR scale allowed the evaluation of general cognitive judgements regarding the perception of 13 sources of risk clustered in a single dimension $\left(R_{l}\right.$ sales price, $R_{2}$ amount to market, $R_{3}$ price of the inputs, $R_{4}$ yield, $R_{5}$ loss of assets, $R_{6}$ sicknesses of the employees, $R_{7}$ interest rate, $R_{8}$ currency exchange rate, $R_{9}$ access to loans, $R_{10}$ climatic events, $R_{11}$ diseases or pests, $R_{12}$ institutional environment in the country, and $R_{13}$ legal).

\section{Statistical analysis}

Statistical analysis of the results was done with the software SPSS 22.0 for Windows in Spanish version. The extraction of factors for the ISR scale was done through principal component analysis, considering eigenvalues greater than 1 . The internal consistency of the scale was calculated using the Cronbach's alpha coefficient. The KMO (Kaiser-Meyer-Olkin) sample adequation index and the Bartlett's sphericity test (HAIR et al., 1999) were used for the validity of the results. In a first stage, the perceptions of the sources of risk were studied using analysis of frequencies and descriptive analysis. For comparisons three field sizes were considered based on the number of permanent workers: $1=$ small (up to 5 workers), 2 medium (between 6 and 12 workers), and $3=$ large (more than 12 workers). To study the differences in the average evaluation of the sources of risk perceived by the growers that represent different field sizes, the average values obtained were compared using $F$ tests for one factor analysis of variance (ANOVA). These mean that differences of means between growers (owners and managers), or according to grower's size, were analyzed using a one-way ANOVA F test and t-test for independent samples after first applying the Levene's test of variance homogeneity. The correlations between the specified perceptions of the sources of risk were calculated using the Spearman's correlation coefficient of ordered rho ranks (PAGANO, 2006). This is because the relationships are between categorical variables in an ordinal scale (or rank orders). Two levels of statistical significance were used: $* p<0.05$ and $* * p<0.01$. For the factorial analysis the varimax KAISER's (1958) criterion of factors rotation was used. Finally, a perception analysis of the sources of risk was done according to type of grower (owner vs managers).

\section{Results and Discussion}

\section{Correlations among sources of risk}

The correlation matrix of the 13 sources of risk $\left(R_{i} / i=1, \ldots, 13\right)$ in the ISR scale is presented in Table 1. Upon examining the correlations it can be inferred that there is a significant superposition between some types of risk sources.

For instance, there is a significant correlation $(\mathrm{r}=0.45 ; p<0.01)$ between sale price $\left(R_{l}\right)$ and amount to market $\left(R_{2}\right)$, variables which are directly proportional. This suggests that as sources of risk both variables are at the same time more (or less) important for the growers. This can be explained since according to the law of demand, price and amount sold move in opposite directions, that is, a higher sale price is associated with a lower quantity demanded and vice versa (MAS-COLELL et al., 1995). Our results suggest that the growers associate with a higher probability the occurrence at the same time of both factors (or neither of both). The climatic events $\left(R_{10}\right)$ constitute an interesting source of risk for the growers. The high correlations between $R_{10}$ and $R_{10}$ with $R_{2}$, and with yield $\left(R_{4}\right)$, can be explained by the fact 
that these factors normally occur concurrently; a negative climatic event brings along a lower yield, a lower yield translates into a lower amount to market, and given the elasticity in the demand, this finally has an incidence in the sales price. Thus the growers associate these factors as risks of simultaneous occurrence that finally influence the profitability of the business.

The high correlation $(\mathrm{r}=0.52 ; p<0.01)$ between institutional $\left(R_{12}\right)$ and legal $\left(R_{13}\right)$ risks can be explained in a similar manner; thus, the growers associate the institutional and legal environments as factors that are characterized by the presence (or absence) of both. The high correlations between $R_{12}$ and $R_{13}$ with interest rate $\left(R_{7}\right)$, exchange rate $\left(R_{8}\right)$, and access to loans $\left(R_{9}\right)$, seem to reflect the learning derived from experience. This means that the risk perception of the growers reflects their passed experience. The presence of institutional or legal risks (for instance, modifications to laws related with agriculture), normally brings along measures of agricultural policies that smooth the effects; for instance, through preferential interest rates, easier access to foreign currencies or soft loans. The high correlations between pests and diseases $\left(R_{11}\right)$ with $\left(R_{7}\right),\left(R_{8}\right)$ and $\left(R_{9}\right)$ should have a similar explanation, that is, after the attack of pests and diseases that affect the crop, authorities develop support measures for the growers based on financial coverage instruments.

\section{Factorial analysis}

From the principal components analysis and orthogonal rotation varimax, the charges of rotated factors of the risk sources were analyzed for the whole sample of growers. The KMO measure for data sufficiency was $0.75(p<0.01)$ and Bartlett's sphericity test had statistical significance $\left.\mathrm{X}^{2}=524.1 ; p<0.01\right)$. The results of the Bartlett's test and the KMO allowed rejecting the hypothesis that the correlations matrix is an identity matrix and that the partial correlations between the variables are small, respectively. Therefore, the factorial model for the sources of risk was significant $(p<0.01)$ and adequate. For the total of the sample, the procedure of rotation of factors revealed a clustering of the sources of risk in four independent factors (or subjacent variables), that explain the configuration of the correlations of the set of 13 sources of risk (Table 2).

Latent roots criteria were specified (eigenvalues greater than 1) for the four factors which explain $64.9 \%$ of the total variance. Factor 1 (Production Variables) included: $R_{3}, R_{5}, R_{6}$, and $R_{9}$. Factor 2 (Market and Climatic Events) included: $R_{1}, R_{2}$ and $R_{10}$. Factor 3 (Financial and Institutional) incorporated: $R_{7}, R_{9}$ y $R_{12}$. Factor 4 (Yield and Legal) included: $R_{4}, R_{11}$ and $R_{13}$. The Cronbach's alpha values for the factors varied between 0.55 and 0.79 which suggests an adequate reliability for these factors.

Table 1. Spearman's rho correlation matrix for 13 items in the scale of Importance of Sources of Risk for blueberry growers in the Maule Region, Chile (ISR)

\begin{tabular}{|c|c|c|c|c|c|c|c|c|c|c|c|c|c|}
\hline & $\mathrm{R}_{1}$ & $\mathrm{R}_{2}$ & $\mathrm{R}_{3}$ & $\mathrm{R}_{4}$ & $\mathrm{R}_{5}$ & $\mathrm{R}_{6}$ & $\mathrm{R}_{7}$ & $\mathrm{R}_{8}$ & $\mathrm{R}_{9}$ & $\mathrm{R}_{10}$ & $\mathrm{R}_{11}$ & $\mathrm{R}_{12}$ & $\mathrm{R}_{13}$ \\
\hline $\mathrm{R}_{1}$ : Sales price & 1.00 & $0.45^{* *}$ & 0.13 & $0.20^{*}$ & 0.14 & 0.10 & 0.17 & $0.19^{*}$ & 0.11 & $0.36 * *$ & 0.16 & $0.31 * *$ & 0.09 \\
\hline $\mathrm{R}_{2}$ : Amount to market & & 1.00 & $0.27 * *$ & $0.32 * *$ & $0.24 * *$ & $0.28 * *$ & $0.19^{*}$ & $0.35^{* *}$ & 0.10 & $0.42 * *$ & 0.13 & $0.22 *$ & 0.05 \\
\hline $\mathrm{R}_{3}$ : Prices of inputs & & & 1.00 & $0.18^{*}$ & $0.47 * *$ & $0.48 * *$ & $0.41 * *$ & $0.27 * *$ & $0.35^{* *}$ & $0.22 *$ & $0.36^{* *}$ & 0.23 & $0.25^{* *}$ \\
\hline $\mathrm{R}_{4}$ : Yield & & & & 1.00 & $0.23^{*}$ & 0.09 & 0.00 & $0.29 * *$ & 0.06 & $0.36^{* *}$ & 0.11 & 0.08 & $0.19^{*}$ \\
\hline $\mathrm{R}_{5}:$ Loss of actives & & & & & 1.00 & $0.61^{* *}$ & $0.40 * *$ & $0.38 * *$ & $0.45^{* *}$ & 0.11 & $0.40 * *$ & $0.37^{* *}$ & $0.42^{* *}$ \\
\hline $\mathrm{R}_{6}$ : Personnel sicknesses & & & & & & 1.00 & $0.48 * *$ & $0.30 * *$ & $0.43 * *$ & $0.19 * *$ & $0.37 * *$ & $0.32 * *$ & * $0.34 * *$ \\
\hline $\mathrm{R}_{7}:$ Interest rate & & & & & & & 1.00 & $0.39 * *$ & $0.53 * *$ & 0.12 & $0.42 * *$ & $0.58 *$ & $0.25 * *$ \\
\hline $\begin{array}{l}\mathrm{R}_{8} \text { : Currency exchange } \\
\text { rate }\end{array}$ & & & & & & & & 1.00 & $0.21^{*}$ & $0.24 * *$ & $0.36 * *$ & $0.31 * *$ & $0.23 * *$ \\
\hline $\mathrm{R}_{9}:$ Access to loans & & & & & & & & & 1.00 & 0.13 & $0.34 * *$ & $0.24 * *$ & $0.29 * *$ \\
\hline $\mathrm{R}_{10}$ : Climatic events & & & & & & & & & & 1.00 & $0.34 * *$ & $0.19^{*}$ & -0.03 \\
\hline $\mathrm{R}_{11}:$ Pests and diseases & & & & & & & & & & & 1.00 & $0.48^{* *}$ & $0.45^{* *}$ \\
\hline $\mathrm{R}_{12}$ : Institutional & & & & & & & & & & & & 1.00 & $0.52 * *$ \\
\hline $\mathrm{R}_{13}$ : Legal & & & & & & & & & & & & & 1.00 \\
\hline
\end{tabular}

${ }^{1}$ Significant correlation at $* \mathrm{p}<0.05$ (bilateral) $\mathrm{y} * * \mathrm{p}<0.01$. 
According to the factorial analysis our results are consistent with the ones reported in the literature. The six factors reported by GEBREEGZIABHER and TADESSE (2014) and the two factors of ULLAH et al. (2016) are coincident with the four factors obtained in this study. This means that independent of the localization of the growers, there are risks that are perceived in a similar manner by all of them, which can be grouped in factors that are also transversals.

\section{Perception of sources of risk}

Risks do not have the same relevance for the growers. Five risks (in decreasing order of importance) showed up clearly from the results (Table 2): climatic events, sale prices, yield, amount to market and variability in currency exchange rate. The ranking of sources of risk in decreasing order shows that, as suggested by the most recent literature, the growers consider the climatic events as the most important source of risk (MARTIN, 1996; GREINER et al., 2008; KUNDZEWICZ; KOZYRA, 2011; OLESEN et al., 2011; SMRKULJ; NJAVRO, 2016; SULEWSKI; KŁOCZKO-GAJEWSKA, 2014). The sources of risk that the growers perceive as the most important ones are also consistent with the international experience. The risks of yield were considered as very relevant in the studies reported by BAGHERI \& FAMI (2016), HARWOOD et al. (1999), MEUWISSEN et al. (2001) y SMRKULJ \& NJAVRO (2016). Meanwhile, risks associated with the sale price were relevant in the research reported by BAGHERI; FAMI (2016), MARTIN
(1996), MEUWISSEN et al. (2001), HALL et al. (2003). As in our study, BAGHERI; FAMI (2016) also reported as relevant the risks of marketing. This means that there are risks that are common to all agricultural producers which are perceived as very relevant and that eventually could constitute elements for adopting common strategies to face risks. Besides, these risks that are common to agricultural producers could become inputs for the design of agricultural policies as well as instruments of risks management, either financial or operational coverage.

It seems interesting to evaluate some risks not included in this study. For example, the lack of production capacity reported by AĞIR et al. (2015), or the number and surface area of the assets considered, the number of land use types or the number of damage functions (SAINTGEOURS et al., 2015), farm household characteristics and farmers' access to publically provided services including agricultural credit and information (ULLAH et al., 2015b; ULLAH et al., 2016).

The average evaluation of the five risks considered as the most relevant by the growers, did not show statistical differences when owners and managers were compared. Also there were no significant differences when comparing the various field sizes. This could reflect the fact that those risks are a wide concern for all growers. The average scores for the risk linked to the variability in currency exchange rate and access to loans were statistically different between owners and managers. Both sources of risk were more important for the owners than for the managers. This could be explained by the fact that the role of the managers normally deals with aspects that are

Table 2. Ranking of sources of risk in decreasing importance, and factorial analysis (Kaiser's varimax factor rotation procedure), of growers (owners and managers) of blueberry fields in the Maule Region, Chile $(\mathrm{n}=124)$

\begin{tabular}{|c|c|c|c|c|c|c|c|c|c|c|}
\hline \multirow{2}{*}{ Source of risk } & \multicolumn{3}{|c|}{$\begin{array}{l}\text { Ranking for the } \\
\text { whole sample }\end{array}$} & \multicolumn{7}{|c|}{ Ranking according to grower's size ${ }^{a}$ Factorial load for risks factors ${ }^{b}$} \\
\hline & Average & S.D. & Sig. ${ }^{c}$ & Small & Medium & Large & 1 & 2 & 3 & 4 \\
\hline $\mathrm{R}_{10}$ : Climatic events & 3.89 & 0.32 & & 3.86 & 3.91 & 3.90 & & 0.71 & & \\
\hline $\mathrm{R}_{1}$ : Sales price & 3.75 & 0.49 & & 3.73 & 3.77 & 3.76 & & 0.69 & & \\
\hline $\mathrm{R}_{4}$ : Yield & 3.74 & 0.54 & & 3.69 & 3.79 & 3.72 & & 0.50 & & 0.67 \\
\hline $\mathrm{R}_{2}$ : Amount to market & 3.73 & 0.46 & & 3.75 & 3.77 & 3.66 & & 0.78 & & \\
\hline $\mathrm{R}_{8}$ : Currency exchange rate & 3.72 & 0.50 & $\dagger$ & 3.71 & 3.71 & 3.72 & & & 0.68 & \\
\hline $\mathrm{R}_{9}$ : Access to loans & 3.67 & 0.77 & $* \dagger$ & 3.44 & 3.53 & 3.00 & 0.75 & & & \\
\hline $\mathrm{R}_{11}:$ Pests and diseases & 3.52 & 0.62 & $* *$ & 3.60 & 3.41 & 3.45 & 0.47 & & 0.42 & 0.48 \\
\hline $\mathrm{R}_{3}$ : Prices of inputs & 3.32 & 0.74 & & 3.38 & 3.38 & 3.17 & 0.69 & 0.30 & & \\
\hline $\mathrm{R}_{13}$ : Legal & 3.23 & 0.74 & $* *$ & 3.20 & 3.29 & 3.28 & 0.36 & & 0.32 & 0.70 \\
\hline $\mathrm{R}_{12}:$ Institutional & 3.20 & 0.73 & & 3.16 & 3.15 & 3.31 & & & 0.84 & \\
\hline $\mathrm{R}_{5}:$ Loss of actives & 3.14 & 0.80 & $* *$ & 3.35 & 3.09 & 2.86 & 0.71 & & & \\
\hline $\mathrm{R}_{7}$ : Interest rate & 3.11 & 0.81 & & 3.20 & 3.00 & 3.01 & 0.51 & & 0.68 & \\
\hline alfa de Cronbach para factores & & & & & & & 0.79 & 0.66 & 0.72 & 0.55 \\
\hline
\end{tabular}

$(1)^{a}$ The ranking for the sources of risk corresponds to the average score $(1=$ very important, $4=$ irrelevant $)$ of the whole sample and for different grower sizes. It includes small $(\mathrm{n}=58)$, medium $(\mathrm{n}=37)$ and large growers $(\mathrm{n}=29)$, which were classified according to the number of permanent workers in the field $(1=$ up to 5 workers, $2=6$ to 12 workers, $3=$ more than 12 workers $)$.

${ }^{\mathrm{b}}$ The factors whose weight (load) is $>|0.40|$ are shown in bold. The factors whose weight (load) is $<|0.30|$ were excluded.

${ }^{\mathrm{c}}$ The symbol $\uparrow(\mathrm{p}<0.05)$ shows significant differences in the average scores between owners and managers. The symbols $*(\mathrm{p}<0.05)$ and $* *(\mathrm{p}<0.01)$ shows significant differences in the average scores between small, medium and large growers. In both cases the test is based on $F$ tests of one-factor analysis of variance (ANOVA). 
more operational within the value chain, while the owners regularly participate throughout the value system of the business. Given the fact that we did not find significant differences in those variables which are more directly related with generating the fluxes of expected benefits and costs of the business (such as sale price, quantity to market, or yield), it does not then seem reasonable to think in some problem of agency. This allows us to put forward the hypothesis that owners and managers have as their only objective function to maximize the current value of the fluxes generated by the business. On the other hand, the average scores of the risks associated with pests and diseases, legal risks and the possibility of losing the actives were statistically different $(p<0.01)$ for the various field sizes. This implies that the risks associated with pests and diseases and the possibility of losing the actives are more important for the small growers, while the legal risks are more important for the medium-size growers. The access to loans is also a risk perceived as the most important by the mid-size growers, but with a lower level of significance $(p<0.05)$.

Even though the risks are the same for the whole sample, all the risks do not have the same relevance for the growers that are owners of the fields. The five risks (in decreasing order of importance) were (Table 3): climatic events, variability in the currency exchange rate, sales price, quantity to market and yield. The climatic events are the most important source of risk for this group and are more important for the small-size field owners than for the large field-size owners $(p<0.05)$. In the case of the growers that are managers of the operation, the five most important risks (in decreasing order of importance) were (Table 4): climatic events, yield, sales price, quantity to market and variability in the currency exchange rate. The average scores for risks associated with pests and diseases and price of inputs were statistically different $(p<0.01)$ for the different field sizes. This implies that the risks associated with pests and diseases and the possibility of changes in the price of inputs are more relevant for the small growers. On the other hand, legal risks are perceived as the most important risk by medium-size growers, but with a lower level of significance $(p<0.05)$. These results allow us to infer that the significant differences in the perception of the risks are more important for the small growers. This can be explained by the fact that the small growers normally have lower stocks of productive resources (such as capital or land); and also that they are less diversified. The occurrence of negative events would then have a greater effect on their expected fluxes and their patrimony.

Our results are consistent with those published in the literature. For instance, as established by DILLON (1971), ANDERSON et al. (1977), and NEWBERY; STIGLITZ (1981), the relevance for the blueberry growers of the risk associated to the sales prices and yields. They are also consistent with reports by other authors (BAQUET et al., 1997; JUST; POPE, 2002; HARDAKER et al., 2004), with respect to the risks of yield, prices and finances.

As suggested GEBREEGZIABHER and TADESSE (2014) our findings also indicate that perceptions of risk and management strategies are farmer-specific; therefore, policy-makers need to consider tailor-made strategies that would address farmers' individual motives to manage risks. Also, our results have implications for agricultural policy makers, extension and advisory services on the brink of subsidy targeting policy, as concluded by BAGHERI \& FAMI (2016).

Tabla 3. Ranking of sources of risk in decreasing importance of growers (owners) of blueberry fields in the Maule Region, Chile $(\mathrm{n}=48)$

\begin{tabular}{|c|c|c|c|c|c|c|}
\hline \multirow{2}{*}{ Source of risk } & \multicolumn{3}{|c|}{ Ranking for the whole sample ${ }^{a}$} & \multicolumn{3}{|c|}{ Ranking according to grower's size } \\
\hline & Average & S.D. & Sig. ${ }^{b}$ & Small & Medium & Large \\
\hline $\mathrm{R}_{10}:$ Climatic events & 3.88 & 0.33 & $*$ & 3.88 & & 3.50 \\
\hline $\mathrm{R}_{8}$ : Currency exchange rate & 3.83 & 0.38 & & 3.82 & 3.78 & - \\
\hline $\mathrm{R}_{1}:$ Sales price & 3.81 & 0.45 & & 3.75 & & - \\
\hline $\mathrm{R}_{2}$ : Amount to market & 3.77 & 0.43 & & 3.79 & 3.56 & - \\
\hline $\mathrm{R}_{4}^{2}:$ Yield & 3.75 & 0.53 & & 3.68 & & 3.75 \\
\hline $\mathrm{R}_{9}:$ Access to loans & 3.56 & 0.71 & & 3.56 & 3.56 & 3.50 \\
\hline $\mathrm{R}_{11}:$ Pests and diseases & 3.54 & 0.58 & & 3.59 & 3.44 & 3.25 \\
\hline $\mathrm{R}_{3}$ : Prices of inputs & 3.31 & 0.78 & & 3.26 & 3.44 & 3.50 \\
\hline $\mathrm{R}_{6}$ : Personnel sicknesses & 3.27 & 0.92 & & 3.44 & 2.67 & 3.00 \\
\hline $\mathrm{R}_{13}^{0}$ : Legal & 3.27 & 0.68 & & 3.21 & 3.22 & 3.75 \\
\hline $\mathrm{R}_{5}$ : Loss of actives & 3.23 & 0.75 & & 3.35 & 3.00 & 2.75 \\
\hline $\mathrm{R}_{12}:$ Institutional & 3.13 & 0.84 & & 3.12 & 3.00 & 3.25 \\
\hline $\mathrm{R}_{7}$ : Interest rate & 3.17 & 0.87 & & 3.29 & 2.67 & 3.25 \\
\hline
\end{tabular}

aThe ranking for the sources of risk corresponds to the average score $(1=$ very important $4=$ irrelevant $)$ of the whole sample and for different grower sizes. It includes small $(n=48)$, medium $(n=37)$ and large growers $(n=29)$, which were classified according to the number of permanent workers in the field $(1=$ up to 5 workers, $2=6$ to 12 workers, 3 = more than 12 workers $)$.

${ }^{\mathrm{b}}$ The symbol * shows that the three grower's sizes are statistically different at *p $<0.05$ and $* * \mathrm{p}<0.01$ based on $F$ tests of one-factor analysis of variance (ANOVA) 
Tabla 4. Ranking of sources of risk in decreasing importance of growers (managers) of blueberry fields in the Maule Region, Chile $(n=46)$

\begin{tabular}{|c|c|c|c|c|c|c|}
\hline \multirow{2}{*}{ Source of Risk } & \multicolumn{3}{|c|}{ Ranking for the whole sample } & \multicolumn{3}{|c|}{ Ranking according to grower's size } \\
\hline & Average & SD & Sig. ${ }^{b}$ & Small & Medium & Large \\
\hline $\mathrm{R}_{10}:$ Climatic events & 3.90 & 0.31 & & 3.81 & 3.88 & 3.96 \\
\hline $\mathrm{R}_{4}:$ Yield & 3.74 & 0.55 & & 3.71 & 3.72 & 3.72 \\
\hline $\mathrm{R}_{1}:$ Sales price & 3.71 & 0.51 & & 3.71 & 3.68 & 3.72 \\
\hline $\mathrm{R}_{2}:$ Amount to market & 3.71 & 0.48 & & 3.67 & 3.84 & 3.60 \\
\hline $\mathrm{R}_{8}$ : Currency exchange rate & 3.64 & 0.56 & & 3.52 & 3.68 & 3.68 \\
\hline $\mathrm{R}_{11}:$ Pests and diseases & 3.51 & 0.64 & $* *$ & 3.62 & 3.40 & 3.48 \\
\hline $\mathrm{R}_{6}:$ Personnel sicknesses & 3.43 & 0.81 & & 3.53 & 3.52 & 3.36 \\
\hline $\mathrm{R}_{3}:$ Prices of inputs & 3.33 & 0.72 & $* *$ & 3.57 & 3.36 & 3.12 \\
\hline $\mathrm{R}_{12}:$ Institutional & 3.26 & 0.64 & & 3.24 & 3.20 & 3.32 \\
\hline $\mathrm{R}_{9}:$ Access to loans & 3.24 & 0.78 & & 3.24 & 3.52 & 3.92 \\
\hline $\mathrm{R}_{13}$ : Legal & 3.22 & 0.79 & * & 3.19 & 3.32 & 3.20 \\
\hline $\mathrm{R}_{5}:$ Loss of actives & 3.08 & 0.83 & & 3.33 & 3.12 & 3.88 \\
\hline $\mathrm{R}_{7}:$ Interest rate & 3.07 & 0.77 & & 3.05 & 3.12 & 3.04 \\
\hline
\end{tabular}

(1)The ranking for the sources of risk corresponds to the average score $(1=$ very important, $4=$ irrelevant $)$ of the whole sample and for different grower sizes. It includes small $(\mathrm{n}=58)$, medium $(\mathrm{n}=37)$ and large growers $(\mathrm{n}=29)$, which were classified according to the number of permanent workers in the field $(1=$ up to 5 workers, $2=6$ to 12 workers, 3 = more than 12 workers).

${ }^{\mathrm{b}}$ The symbol * shows that the three grower's sizes are statistically different at $* \mathrm{p}<0.05$ and $* * \mathrm{p}<0.01$ based on $F$ tests of one-factor analysis of variance (ANOVA).

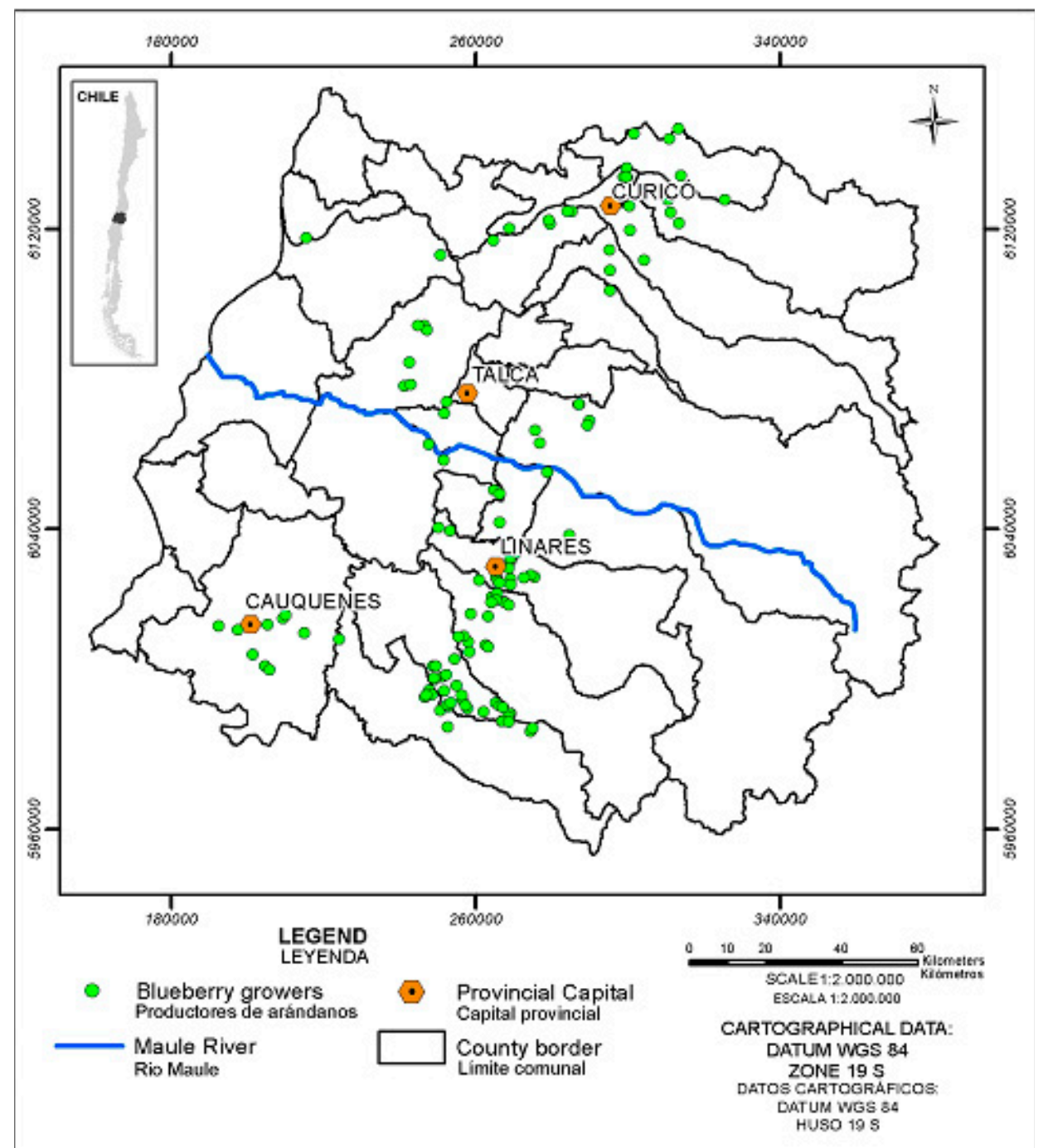

Figure 1. Geo-spatial distribution of blueberry growers in the Maule Region (Chile). 


\section{Conclusions}

Most studies have concentrated in identifying what are the sources of risk that the farmers perceive as the most important. This is a fundamental aspect in designing adequate risk management strategies in real life. Given this situation, the main objective of this study was to learn about the perception of the main sources of risk that face the blueberry growers in the Maule Region, Chile. Moreover, two specific objectives were established: 1) rank the sources of risk according to the importance assigned by the growers, and 2) compare the perception of the sources of risk between owners and field managers.

The blueberry growers considered climatic events as the most important source of risk, followed by variability in sales price, yield, quantity to market and currency exchange rate. Given that we did not find statistically significant differences in the perception of risk when comparing field owners and managers, as well as among growers in fields of different sizes, we infer that those risks would be a widespread concern for blueberry growers. Besides, given that we did not find significant differences in those variables more directly linked with the generation of fluxes of benefits and expected costs of the business, we a priori discard the existence of a problem of agency.

The findings obtained in study might seem as very simple and evident, but it has remarkable practical implications for the design of public agricultural policies. This means that this information can help to better define the strategies for risk management for the economical development of agriculture. Besides, the incorporation of new public instruments for agricultural risk management, such as subsidies or conditional cash transfers, could affect the perception of risks sources through the incorporation of institutional uncertainty. One important methodological limitation of this study is the use of the ISR scale, since this scale has 13 sources of risk which have to be answered in a scale of four points, and then does not include the median. This mean that facing come type of risk, the interviewed has no possibility of declaring himself indifferent. Given this, in future studies we suggest that this scale should be modified to a five points scale which would allow the incorporation of the median.

\section{References}

AĞIR, H.B.; SANER, G.; ADANACIOĞLU, H. Risk sources encountered by farmers in the open field production of strawberry and risk management strategies: a case of Menemen - Emiralem district of Izmir. Tarim Bilimleri Dergisi, Ankara, v.21, n.1, p.13-25, 2015.
ANDERSON, J.R.; DILLON, J.L.; HARDAKER J.B. Agricultural decision analysis. Ames: Iowa State University Press, 1977.

BAGHERI, A.; FAMI, H.S. Potato growers' risk perception: a case study in Ardabil province of Iran. Journal of Agricultural Science and Technology, Tehran, v.18, n.1, p.55-65, 2016.

BAQUET, A.; HAMBLETON, R.; JOSE, D. Understanding agricultural risks: production, marketing, financial, legal, and human resources. Kansas City: USDA Management Agency, 1997.

BUGUK, C.; HUDSON, D.; HANSON, T. Price volatility spillover in agricultural markets: an examination of U.S. catfish markets. Journal of Agricultural and Resource Economics, Bozeman, v.28, n.1, p.86-99, 2003.

CAO, R.; CARPENTIER, A.; GOHIN, A. Measuring farmers' risk aversion: the unknown properties of the value function. In: EAAE 2011 CONGRESS; 2011; Zurich.

CAZANGA, R.; LEIVA, C. Antecedentes técnicos y económicos para la producción de Berries y Pistacho en la Región del Maule. Santiago: Centro de Información de Recursos Naturales, 2013. (CIREN, 174).

CIREN - Centro de Información de Recursos Naturales. Evolución de la superficie plantada de arándanos y sus variedades en Chile. Santiago, 2014. Disponible em: $\leq \mathrm{http}: / /$ bibliotecadigital.ciren.cl/ handle/123456789/1247>. Acesso em: 10 jul. 2017.

DILLON, J.L. An expository review of Bernoullian decision theory in agriculture. Review of Marketing and Agricultural Economics, Sydney, v.39, n.1, p.3-80, 1971.

FAUL, F.; ERDFELDER, E.; BUCHNER, A.; LANG, A.G. Statistical power analyses using G* power 3.1: tests for correlation and regression analyses. Behavior Research Methods, Austin, v.41, n.4, p.1149-1160, 2009.

FLATEN, O.; LIEN, G.; KOESLING, M.; VALLE, P. S.; EBBESVIK, M. Comparing risk perceptions and risk management in organic and conventional dairy farming: empirical results from Norway. Oslo: Norwegian Agricultural Economics Research Institute (NILF), 2004. 26 p. (Working Paper, 21) 
GARCÍA, L. La gestion du risque sur le marché des matières premières agricoles : application au secteur viti-vinicole. 2006. 286 f. Thèse (Doctorat) - Université d'Avignon, Paris, 2006.

GEBREEGZIABHER, K.; TADESSE, T. Risk perception and management in smallholder dairy farming in Tigray, Northern Ethiopia. Journal of Risk Research, Abingdon, v.17, n.3, p.367-381, 2014.

GREINER, R.; PATTERSON, L.; MILLER, O. Motivation, risk perceptions and adoption of conservation practices by farmers. Agricultural Systems, Oxford, v.99, n.2-3, p.86-104, 2008.

HAIR, J.; ANDERSON, R.; TATHAM, R.; LACK, W. Análisis multivariante. Madrid: Prentice Hall Internacional, 1999.

HALL, D.C.; KNIGHT, T.O.; COBLE, K.H.; BAQUET, A.E.; PATRICK, G.F. Analysis of beef producers' risk management perceptions and desire for further risk management education. Review of Agricultural Economics, East Lansing, v.25, n.2, p.430-448, 2003.

HARDAKER, J.B.; HUIRNE, R.M.B.; ANDERSON, J.R.; LIEN, G. Coping with Risk in Agriculture. $2^{\text {nd }}$ ed. Cambridge: CABI Publishing, 2004.

HARWOOD, J.; HEIFNER, R.; COBLE, K. PERRY, J.; SOMWARU, A. Managing risk in farming: concepts, research, and analysis. Washington: USDA, 1999.

JENSEN, M., MECKLING, W. Theory of the firm: managerial behavior, agency costs and ownership structure. Journal of Financial Economics, Amsterdam, v. 3 , n. 4 , p. $305-360,1976$.

JUST, R.E.; POPE, R.D.A. Comprehensive assessment of the role of risk in u.s. agriculture. Norwell: Kluwer Academic Publisher, 2002.

KAISER, H.F. The varimax criterion for analytic rotation in factor analysis. Psychometrika, New York, v.23, p.187200, 1958 .

KHAN, Y.; NIKITINA, G.; GRIGORUK, V.; AKIMBEKOVA, G. Specifics of agricultural risks insurance system in the republic of Kazakhstan. Journal of Environmental Management and Tourism, Craiova, v.8, n.1, p.17-30, 2017.
KUNDZEWICZ, Z.; KOZYRA, J. Reducing impacts of climatic threats to agriculture and rural areas. Polish Journal of Agronomy, Pulawy, v.7, p.68-81, 2011.

LOBOS G.; VIVIANI J.L. Description des perceptions des sources de risque des producteurs vitivinicoles. Évidence empirique pour le Chili. Économie Rurale, Paris, v.316, p.48-61, 2010.

LOBOS, G., PETRI J.L. Volatilidad de precios internacionales recibidos por los productores de kiwis y manzanas frescas chilenas. Revista Brasileira de Fruticultura, Jaboticabal,v.30, n.1, p.133-139, 2008.

MARTIN, S. Risk management strategies in New Zealand agriculture and horticulture. Review of Marketing and Agricultural Economics, Sydney, v.64, n.1, p.31-44, 1996.

MAS-COLELL, A.; WHINSTON, M.D.; GREEN, J.R. Microeconomic theory. New York: Oxford University Press, 1995.

MENA, C. (Ed.). Geo-información para el ordenamiento territorial: Experiencias, aplicaciones y avances. Santiago: Editorial Fuerza Aérea de Chile, 2013.

MEUWISSEN, M.P.M.; HUIRNE, R.B.M.; HARDAKER, J.B. Risk and risk management: an empirical analysis of Dutch livestock farmers. Livestock Production Science, Amsterdam, v.69, p.43-53, 2001.

MOSCHINI, G.C.; HENNESSY, D.A. Uncertainty, risk aversion, and risk management for agricultural producers. In: GARDNER, B.L.; RAUSSER, G.C. (Ed.). Handbook of agricultural economics. New York: Elsevier-NorthHolland, 2001. v.1, p.87-153.

NEWBERY, D. M.; STIGLITZ, J. E. The theory of commodity price stabilization: a study in the economics of risk. New York: Oxford University Press, 1981.

NGUYEN, N.C.; WEGENER, M.; RUSSELL, I.; CAMERON, D.; COVENTRY, D.; COOPER, I. Risk management strategies by Australian farmers: two case studies. Australian Farm Business Management Journal, Orange, v.4, n.1/2, p.23-30, 2007.

ODEPA - Oficina de Estudios y Políticas Agrarias. Boletín fruta fresca. Gobierno de Chile: Ministerio de Agricultura, 2017. Disponivel em: $\leq$ http://www.odepa. gob.cl>. Acesso em: 21 abr. 2017. 
ODEPA-CIREN. Catastro frutícola. Santiago, 2016. Disponível em: <http://www.odepa.cl/wp-content/ uploads/2016/08/Catastro-Fruticola-VII-Maule-2016. pdf $>$. Acesso em: 21 jul. 2017.

OLESEN, J.E.; TRNKA, M.; KERSEBAUM, K.C.; SKJELVAG, A.O.; SEGUIN, B.; PELTONEN-SAINIO, P.; ROSSI, F.; KOZYRA, J.; MICALE, F. Impacts and adaptation of European crop production systems to climate change. European Journal of Agronomy, Amsterdam, v.34, p.96-112, 2011.

PAGANO, R.R. Estadística para las ciencias del comportamiento. 7.ed. México: Editorial Thomson, 2006.

RETAMALES, J.B.; HANCOCK, J.F. Blueberries. Oxfordshire: CABI, 2012.

SAINT-GEOURS, N.; GRELOT, F.; BAILLY, J.S.; LAVERGNE, C. Ranking sources of uncertainty in flood damage modelling: a case study on the cost-benefit analysis of a flood mitigation project in the Orb Delta, France. Journal of Flood Risk Management, Oxford, v.8, n.2, p.161-176, 2015.

SAN MARTÍN, J.M. Interacción entre mecanismos internos y externos de gobierno como elemento detonante de la creación de valor: un estudio internacional. Revista Brasileira de Gestão de Negócios, São Paulo, v.14, n.43, p.143-158, 2012.

SIMÕES, D.; CABRAL, A.C.; DE OLIVEIRA, P. A. Citriculture economic and financial evaluation under conditions of uncertainty. Revista Brasileira de Fruticultura, Jaboticabal, v.37, n.4, p.859-869, 2015.
SMRKULJ, H.; NJAVRO, M. Risk management on the winegrowing farms at Northwest Croatia. Journal of Central European Agriculture, Zacreb, v. 17, n.1, p.221235, 2016.

SONKKILA, S. Farmers' decision-making on adjustment into the EU. Helsinki: University of Helsinki, 2002. $160 \mathrm{p}$.

SULEWSKI, P.; KŁOCZKO-GAJEWSKA, A. Farmers' risk perception, risk aversion and strategies to cope with production risk: an empirical study from Poland. Studies in Agricultural Economics, Budapest, v.116, p.140-147, 2014.

ULLAH, R.; SHIVAKOTI, G.P., REHMAN, M., KAMRAN, M.A. Catastrophic risks management at farm: the use of diversification, precautionary savings and agricultural credit. Pakistan Journal of Agricultural Sciences, Oxford, v.52, n.4, p.1135-1142, 2015b.

ULLAH, R.; SHIVAKOTI, G.P.; ALI, G. Factors effecting farmers' risk attitude and risk perceptions: the case of Khyber Pakhtunkhwa, Pakistan. International Journal of Disaster Risk Reduction, Oxford, v.13, p.151-157, 2015a.

ULLAH, R.; SHIVAKOTI, G.P.; ZULFIQAR, F.; KAMRAN, M.A. Farm risks and uncertainties: sources, impacts and management. Outlook on Agriculture, London, v.45, n.3, p.199-205, 2016.

WILSON, P. N.; DAHLGRAN, R. D.; CONKLIN, N. C. "Perceptions as reality" on large-scale dairy farms. Review of Agricultural Economics, East Lansing, v.15, n.1, p.89-101, 1993. 